\title{
Impact of land protection in soil quality properties and in earthworm biomass in Venezuelan savannas
}

\author{
D. López-Hernández*, L. Hernández, A. Ojeda, E. Quintero and S. Caipo \\ Instituto de Zoología y Ecología Tropical. Facultad de Ciencias. Universidad Central de Venezuela, Caracas, \\ Caracas 1041-A, Venezuela. \\ *Corresponding author: danilo.lopez@ciens.ucv.ve
}

\begin{abstract}
We studied soil parameters and the earthworm biomass and density in a protected savanna (PS) from fire and cattle raising for more than forty years located at Estación Biológica de los Llanos, Venezuela (EBLL), and an adjacent non-protected savanna (NS) under frequent burning and agricultural activities, located less than 1 $\mathrm{km}$ apart. Earthworm sampling was carried out at the end of the dry season (April), and at the peak of the wet season (July-August) using a hand sorting extraction method. In each plot, five to seven sampling units were selected corresponding to soil monoliths of $25 \times 25 \times 30 \mathrm{~cm}$. The main physical, chemical, microbial (biomass) and enzymatic activities of soils in both systems were estimated. The presence of an abundant litter layer under the tree canopies in the PS have increased the soil water retention capacity, the organic-C, C-microbial biomass, dehydrogenase activity and fertility levels respect NS. This may allow for an increase in the density and biomass of earthworms in the PS compared with the adjacent NS. The systems were characterized by abundance in juvenile individuals belonging to the Glossoscolecidae family; two different morphotypes of the genus Aicodrilus were registered. Earthworms found were located in an endo-anecic ecological category. Results suggest that, agricultural management in savannas by modification of physical and biochemical soil properties can decrease an important fraction of pedofauna, particularly their earthworm communities. However, earthworm populations and soil quality indicators can be restored after long-term protection.
\end{abstract}

Keywords: Soil fertility, macrofauna, Glossoscolecidae, microbial biomass, dehydrogenase, fire

\section{Introduction}

Most of the Orinocollanos'ecosystems are located in dystrophic and well drained soils dominated by grasses such as Trachypogon plumosus Ness., locally known as Trachypogon savannas. In those savannas other shrub and tree like species, such as Curatella americana Linn., Mauritia flexuosa Linn. and Bowdichia virgilioides H.B. and K., can be found; however, they do not form a continuous canopy. In the Orinoco's savannas, Ultisols and Oxisols cover important areas 
characterized by low $\mathrm{pH}$, low nutrient contents and limited $\mathrm{C}, \mathrm{N}$ and $\mathrm{P}$ pools (López-Hernández, 2012). Therefore, llanos' soil types are mostly represented by well-weathered soils resulting from long-term pedogenic processes leading to the establishment of acid-tolerant pedofauna (Jiménez et al., 1998; Hernández et al., 2012). The soil-plant interfaces in tropical savannas, despite their unfertile characteristics, seem to provide convenient micro-environmental conditions for the development of a prolific biological activity, particularly of invertebrates. Within these communities, the macrofauna, defined as the animals greater than or equal to 2 $\mathrm{mm}$ in size, has the most striking effects on the biological and physical-chemical properties of soils (Chapuis-Lardy et al., 2011). Thus, in some savanna soils, earthworms have a dominant role in shaping the soil environment due to their abundance and effects of their biological activities (Decaëns et al., 2004). Moreover, earthworms are ascribed to affect soil fertility and plant growth through the production of casts which affects the availability and nature of both the spatial and trophic resource in soil.

The beneficial effects of the earthworm activities include: i) improvement of soil physical properties which affect soil water retention capacity, drainage, and the formation and degradation of aggregates (Blanchart et al., 1999); ii) chemical and biological effects on the rate of organic matter degradation and nutrient cycling (Chapuis-Lardy et al., 2011; Lavelle et al., 1994; López-Hernández et al., 2004, 2009), and iii) alteration of the composition and activity of microorganisms and soil invertebrates (Lavelle and Spain, 2001). All these processes significantly impact the soil fertility primarily through the release of available forms of nitrogen
(N) and phosphorus (P) (Baker, 2007; ChapuisLardy et al., 2011; Chaoui et al., 2003; Jiménez et al., 2003; López-Hernández et al., 1993) once the soil passes through the gut of the individual earthworm.

The Estación Biológica de los Llanos (EBLL), located in Calabozo, Guárico State, Venezuela has been protected from fire, grazing and cultivation since 1960 . None-the-less, in recent years, despite management efforts occasional fires have occurred. The extended period of protection has resulted in an increased woody component according to San José and Fariñas (1991), however Silva et al. (2001) have revised the information and found that there was an increase in the woody component of the protected EBLL but also in the surrounding man-managed (cattle raising and agricultural activities) plots during the 17-year interval (1960-1977). Total woody cover in the four analyzed plots as a whole increased from $4.5 \%$ to $17.9 \%$. At EBLL due to protection the presence of an abundant litter layer above the soil has resulted in improved physical-chemical and biological properties of the soil (LópezHernández et al., 2008). All those factors may, in turn, have a strong influence in the establishment of the earthworm communities in this protected savanna. However, the existing knowledge of the biology and ecology of earthworms in this region is limited. Work in similar savanna-type ecosystems has suggested that marked climatic seasonality can limit the activity of earthworms to the wet season (Araujo and López-Hernández, 1999; Jiménez et al., 1998; Paoletti, 1999). The main objectives of this contribution are to: 1) analyze the effect of a long period of protection from fire and agricultural activities has had on soil properties in a nutrient-poor savanna which 
generate conditions leaving to the establishment of Oligochaeta communities, and, 2) to present a preliminary report of some biological and ecological aspects of the earthworm populations in this savanna.

\section{Materials and Methods}

\subsection{Site description}

The experimental sites were located about 12 $\mathrm{km}$ southeast of the city of Calabozo $\left(8^{\circ} 56^{\prime} \mathrm{N}\right.$, $\left.67^{\circ} 25^{\prime} \mathrm{W}\right)$, State of Guárico, Venezuela. The study included six experimental plots in one protected savanna (PS) located in the EBLL and six plots in an adjacent non-protected savanna (NS) located in Fundo "La Matica" (Figure 1). PS have been under protection from annual fires and grazing for more than forty years (PS) and the adjacent non-protected savanna (NS) has been grazed at a rate of approximately $0.16 \mathrm{head} /$ ha; and in addition has experienced recurring fires and agriculture practices.

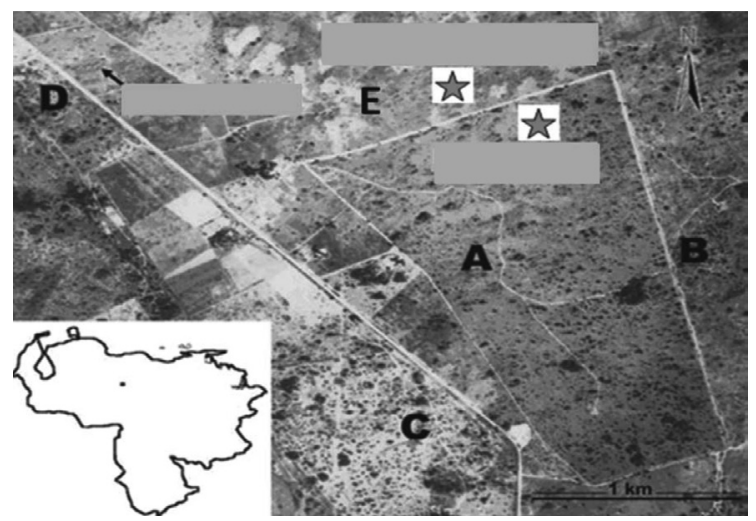

Figure 1. Location of Estación Biológica de los Llanos in Venezuela (EBLL). (A) EBLL protected from fire and cattle raising (PS). (E) Fundo "La Matica", NS (Modified from Silva et al.,2001). The stars denote the sites of sampling.

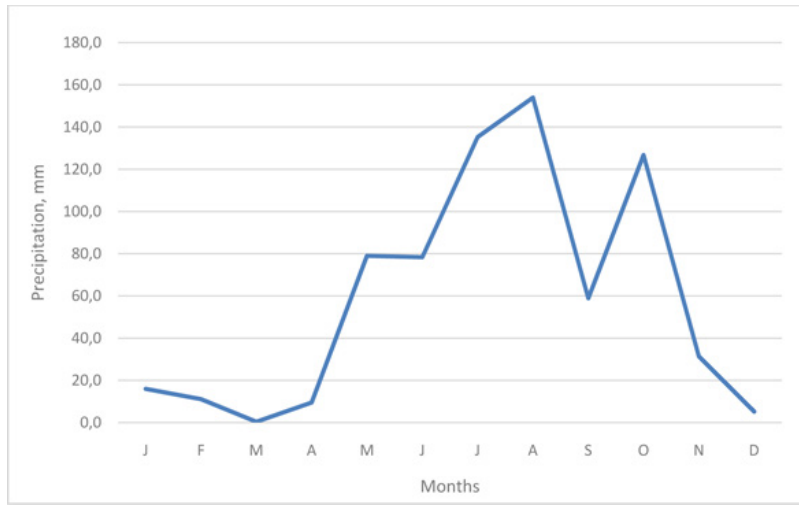

Figure 2. Monthly precipitation (mm) in Calabozo, Estado Guarico, Venezuela during 2009. 
Both sites are located less than $1 \mathrm{~km}$ apart, in the same soil type (Oxisols) with similar texture and relief (Figure 1). EBLL since its creation, has been protected from burning and agricultural activities, besides EBLL have been the place for extensive ecological studies since early sixties (López-Hernández et al., 2008; San José and Fariñas, 1983).

The climate of the zone is megathermic (Aw) with a rainy period which begins in the month of May and ends in November (Figure 2). Annual mean precipitation and temperature are $1364 \mathrm{~mm}$ and $26.7^{\circ} \mathrm{C}$, respectively. The soil is characterized by the presence of a lateritic cuirass near the surface that influences the distribution of vegetation (San José and Fariñas, 1983). This soil has been characterized as a Haplustox, kaolinitic, flat, well-drained, and moderately acidic and has low natural fertility (López-Hernández et al., 2008). Soil texture is between loamy-sandy and sandy-clayey. The herbaceous component of the plant community is constituted mainly of grasses belonging to the genus Trachypogon $\mathrm{sp}$. while the tree component is mostly composed of Curatella americana, Bowdichia virgilioides and Byrsonima crassifolia.

\subsection{Earthworm sampling}

Sampling was carried out in 2009 at the end of the dry season (April) and at the peak of the wet season (July and August). Because of the presence of a lateritic layer or endured lateritic granules at $15-20 \mathrm{~cm}$ depth in many places at the study sites, which made the earthworm sampling very difficult, only six sampling units were selected at random in each study area. At each sampling point, preliminary deeper samplings were carried out $(60 \mathrm{~cm}$ depth) without accounting the presence of deep dwelling species. Therefore a soil monolith (30 cm depth) of $25 \times 25 \times 30 \mathrm{~cm}$ was collected from each selected unit (Anderson and Ingram, 1993) to account for earthworms' biomass and density. Earthworms were extracted and separated by soil strata using a hand sorting extraction method (Anderson and Ingram, 1993) and the biomass and the density of the Oligochaeta were determined. Individuals were then fixed in formaldehyde (10\%) for two days and later preserved in $70 \%$ ethyl alcohol.

\subsection{Soil sampling and determinations}

Soil samples $(0-10,10-20,20-30 \mathrm{~cm})$ were collected during the month of July (wet season) in the protected savanna and in the adjacent nonprotected savanna from the same soil profiles corresponding to the earthworms' collection. After air-drying, samples were further prepared for analyses by crushing and sieving.

After drying and sieving through 2-mm mesh, soil samples were analyzed for soil $\mathrm{pH}$ (measured in a ratio 1:5 soil: water), total organic carbon and total nitrogen (Kjeldahl method) according to Anderson and Ingram (1993). Total and available phosphorus were performed according to Anderson and Ingram (1993). Additionally, some soil physical determinations were done during the earthworm collection. Soil moisture and temperature were measured between 6:00 and 7:00 am at each sampling date. Soil moisture was determined by the gravimetric method, soil temperature with geothermometers located at each sampling depth, bulk density by the method of the hole in the field (López-Hernández et al., 2008), field capacity by the method of Anderson and Ingram (1993) and soil texture (mechanical 
analysis) were analyzed according to (LópezHernández et al., 2008).

Additionally, intact sub samples of the collected superficial soils $(0-10 \mathrm{~cm})$ were used to characterize complementary biochemical and microbial parameters. The intact samples were immediately transported to the laboratory and stored at $4^{\circ} \mathrm{C}$ until analysis.

Triplicate $15 \mathrm{~g}$ of intact soil, were used to determine $\mathrm{N}$ microbial biomass $(\mathrm{N}-\mathrm{MB})$ and $\mathrm{C}$ microbial biomass (C-MB). C-MB and N-MB were determined by the fumigation-extraction method using free-alcohol chloroform (Brookes et al., 1985; Vance et al. 1987). N-MB was calculated as the difference in total $\mathrm{N}$ extracted in the fumigated and non-fumigated soil (Brookes et al., 1985). The C-MB was calculated as the difference between $\mathrm{C}$ extracted in fumigated and non fumigated soils (Vance et al., 1987). Microbial P (P-MB) was also determined by the chloroform fumigation-extraction method. The P-MB was also calculated as the difference between $\mathrm{P}$ extracted in fumigated and non fumigated soils.

Acid phosphatase activity (APA) was determined colorimetrically as the degradation of PNP-P (p-nitrophenyl phosphate) to PNP (p-nitrophenyl) after a $30 \mathrm{~min}$ incubation of $1 \mathrm{~g}$ fresh soil sample at $\mathrm{pH} 6.5$ (Tabatabai and Bremner, 1969), while urease activity was determined according with the method of Tabatabai and Bremner (1972). Dehydrogenase activity (DHA) was determined colorimetrically as the degradation of TTC (triphenyltetrazolium chloride) to TTF (triphenyltetrazoliumformazan) after $24 \mathrm{~h}$ of $1.5 \mathrm{~g}$ fresh soil sample incubation. Values are expressed as mg of TTF released per $\mathrm{kg}$ of dry soil per 24 hours, according to Casida et al. (1964). For microbial and enzymatic activities, values were corrected for humidity contents.

\subsection{Statistical analysis}

An analysis of variance (ANOVA) was performed to assess the differences between the two systems, with a HSD-Tukey post-hoc test of significance. Analyses were performed using the statistical package SPSS 13.0 with a level of significance $p<0.05$. Pearson's correlation coefficients between earthworm density and biomass and the physical parameters were performed using the computer program STATISTICA version 3.1.

\section{Results}

\subsection{Soil physical changes in protected and non-protected savanna}

As a result of the protection of the savanna (PS) in the EBLL some physical parameters were modified in relation to NS (Table 1). The PS soils had greater soil moisture with significant differences between sites $(p<0.05$, Table 1$)$. Field capacity in the PS $(16.4 \% \pm 0.6)$ was significantly greater than that in the NS $(14.1 \% \pm 0.6)$. The PS soils had lower soil temperature in July (0 - 10 $\mathrm{cm})$. The apparent bulk density for the surface layer of soil $(0-10 \mathrm{~cm})$ was significantly lower in the PS $(1.37 \mathrm{~g} / \mathrm{mL} \pm 0.06)$ than in the NS $(1.84$ $\mathrm{g} / \mathrm{mL} \pm 0.38)$ reflecting a lower soil compaction in the PS. The predominant textural class within the profile (data not presented) was the loamysand type (LS), except the surface layer (0 - 10 $\mathrm{cm}$ ) in the NS which was sandy-loam (SL), possibly associated with the tillage management. 
Table 1. Soil physical characteristics in Protected (PS) and in man affected Natural Savanna (NS). Different letters indicate significant differences $(p<0.05)$.

\begin{tabular}{|c|c|c|}
\hline Parameter & NS & PS \\
\hline Temperature $\left({ }^{\circ} \mathrm{C}\right)$ & $27.0 \mathrm{~b}$ & $25.3 \mathrm{a}$ \\
\hline Soil water content $(\%)$ & $10.0 \mathrm{a}$ & $14.4 \mathrm{~b}$ \\
\hline Field capacity $(\%)$ & $14.1 \mathrm{a}$ & $16.4 \mathrm{~b}$ \\
\hline Bulk density $(\mathrm{g} / \mathrm{mL})$ & $1.84 \mathrm{~b}$ & $1.37 \mathrm{a}$ \\
\hline
\end{tabular}

\subsection{Soil chemical changes in protected and non-protected savanna}

Soil chemical parameters $(\mathrm{pH}$, organic matter, nitrogen and phosphorus) in each locality are presented in Table 2. As expected, there was an important increment in soil fertility parameters due to the protection of the savanna. The total contents of organic carbon (OC) and nitrogen in the first $10 \mathrm{~cm}$, tend to be significantly higher in the PS than the NS, that increment decrease with soil depth (Table 2). Total P content in PS is higher compared with NS at $0-10 \mathrm{~cm}$ and $10-20 \mathrm{~cm}$ depth whereas available $\mathrm{P}$ was also in PS respect NS although significance was not reached. The natural acidity of the soil $(\mathrm{pH}$ ranged from 4.1-4.2) was slightly neutralized ( $\mathrm{pH}$ ranged from 4.3-4.8) under protection (PS).

Table 2. Soil chemical characteristics in Protected (PS) and in man affected Natural Savanna (NS). Small letters indicate significant difference between depth and capital letters indicate significant difference between systems $(p<0.05)$.

\begin{tabular}{|c|c|c|c|c|}
\hline Parameter & & $\begin{array}{l}\text { Soil }(0-10 \\
\mathrm{cm})\end{array}$ & Soil $(10-20 \mathrm{~cm})$ & Soil $(20-30 \mathrm{~cm})$ \\
\hline $\mathrm{pH}$ & $\begin{array}{l}\text { PS } \\
\text { NS }\end{array}$ & $\begin{array}{l}4.80 \mathrm{aA} \\
4.10 \mathrm{aB}\end{array}$ & $\begin{array}{l}4.30 \mathrm{bA} \\
4.20 \mathrm{aA}\end{array}$ & $\begin{array}{l}4.30 \mathrm{bA} \\
4.19 \mathrm{aB}\end{array}$ \\
\hline $\mathrm{C}\left(\mathrm{mg} \mathrm{kg}^{-1}\right)$ & $\begin{array}{l}\text { PS } \\
\text { NS }\end{array}$ & $\begin{array}{l}9900 \mathrm{aA} \\
7300 \mathrm{aB}\end{array}$ & $\begin{array}{l}7700 \mathrm{bA} \\
4600 \mathrm{bB}\end{array}$ & $\begin{array}{l}5500 \mathrm{cA} \\
3700 \mathrm{cB}\end{array}$ \\
\hline $\mathrm{N}\left(\mathrm{mg} \mathrm{kg}^{-1}\right)$ & $\begin{array}{l}\text { PS } \\
\text { NS }\end{array}$ & $\begin{array}{l}234 \mathrm{aA} \\
186 \mathrm{aB}\end{array}$ & $\begin{array}{l}180 \mathrm{bA} \\
113 \mathrm{bB}\end{array}$ & $\begin{array}{l}158 \mathrm{bA} \\
110 \mathrm{bB}\end{array}$ \\
\hline $\mathrm{P}\left(\mathrm{mg} \mathrm{kg}^{-1}\right)$ & $\begin{array}{l}\text { PS } \\
\text { NS }\end{array}$ & $\begin{array}{l}77 \mathrm{aA} \\
70 \mathrm{aB}\end{array}$ & $\begin{array}{l}79 \mathrm{aA} \\
68 \mathrm{aB}\end{array}$ & $\begin{array}{l}62 \mathrm{bB} \\
69 \mathrm{aA}\end{array}$ \\
\hline Available $\mathrm{P}\left(\mathrm{mg} \mathrm{kg}^{-1}\right)$ & PS & $0.67 \mathrm{aA}$ & $0.30 \mathrm{aA}$ & $0.30 \mathrm{aA}$ \\
\hline
\end{tabular}


Table 3. Microbial and enzymatic activities in protected (PS) and the natural savanna (NS) in Estación Biológica de los Llanos, Venezuela. Different letters indicate significant differences $(p<0.05)$ between systems.

\begin{tabular}{|c|c|c|}
\hline Parameter & NS & PS \\
\hline & $124 \mathrm{a}$ & $217 b$ \\
\hline Microbial C $\left(\mathrm{mgC} \mathrm{kg}^{-1}\right)$ & & \\
\hline Microbial N $\left(\mathrm{mgN} \mathrm{kg}^{-1}\right)$ & $4.3 \mathrm{a}$ & $4.6 \mathrm{a}$ \\
\hline Microbial quotient (\%) & 1.69 & 2.19 \\
\hline Microbial C/ Microbial N (\%) & 25.7 & 47.3 \\
\hline $\begin{array}{l}\text { Microbial P } \\
\left(\mathrm{mgP} \mathrm{kg}^{-1}\right)\end{array}$ & $5.28 \mathrm{a}$ & $0.99 \mathrm{a}$ \\
\hline $\begin{array}{l}\text { Phosphatase Activity } \\
\left.\text { (mgP-NP kg }{ }^{-1} \mathrm{~h}^{-1}\right)\end{array}$ & $1.13 \mathrm{a}$ & $2.96 \mathrm{a}$ \\
\hline 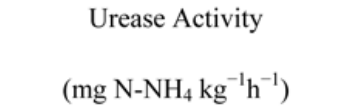 & $0.93 \mathrm{a}$ & $3.27 \mathrm{a}$ \\
\hline $\begin{array}{l}\text { Dehydrogenase activity } \\
\qquad\left(\mathrm{mg} \mathrm{kg}^{-1} 24 \mathrm{~h}^{-1}\right)\end{array}$ & $5.03 \mathrm{a}$ & $13.48 \mathrm{~b}$ \\
\hline
\end{tabular}

\subsection{Microbial biomass and enzymatic} activities in protected and non-protected savanna

The most active form of $\mathrm{C}$ corresponding to the microbial biomass fractions increased significantly in the PS soil compared with the NS soil, similar information was found for the microbial quotient (Table 3). On the contrary, in the case of microbial N-biomass, there was no difference between the two sites; however the microbial $\mathrm{C}$ and $\mathrm{N}$ ratio was higher in PS in concomitance with the higher microbial-C reported in PS. Values of microbial $\mathrm{P}$ were higher in NS than in PS; however there was no significant difference between means.

The phosphatase (PA) and urease (UA) activities (Table 3) in both localities were not different; on the contrary the dehydrogenase activity (DHA) was much higher in PS resembling the data of the C-microbial biomass.

\subsection{Density and biomass of earthworms}

All collected individuals belong to the Glossoscolecidae family; two different morphotypes of the genus Aicodrilus were registered and the earthworms found were located in an endo-anecic ecological category (Hernández et al., 2012). Total average for the density and biomass of earthworms differed greatly between seasons in the two systems, showing higher values in the PS (Figures 3a,b). The average density of earthworms in the PS ranged between 25.6 and 85 individuals $\mathrm{m}^{-2}$, and average biomass varied between 6.92 and 23.23 $\mathrm{g} \mathrm{m}^{-2}$. In the NS earthworms only were found in the wet season, with a mean density of 22.40 individuals $\mathrm{m}^{-2}$ and a mean biomass of $5.17 \mathrm{~g} \mathrm{~m}^{-2}$ (Figure 3b). 


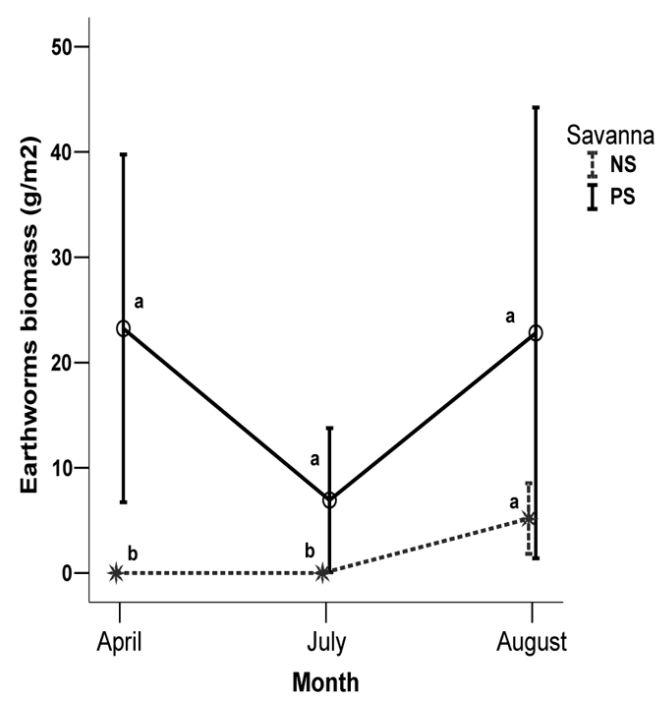

Figure 3a. Mean biomass of earthworms $(\mathrm{g} / \mathrm{m} 2)$ and standard deviation in Protected Savanna (PS, continuous line) and Natural Savanna (NS, dashed line). Different letters indicate significant difference $(p<0.05)$.

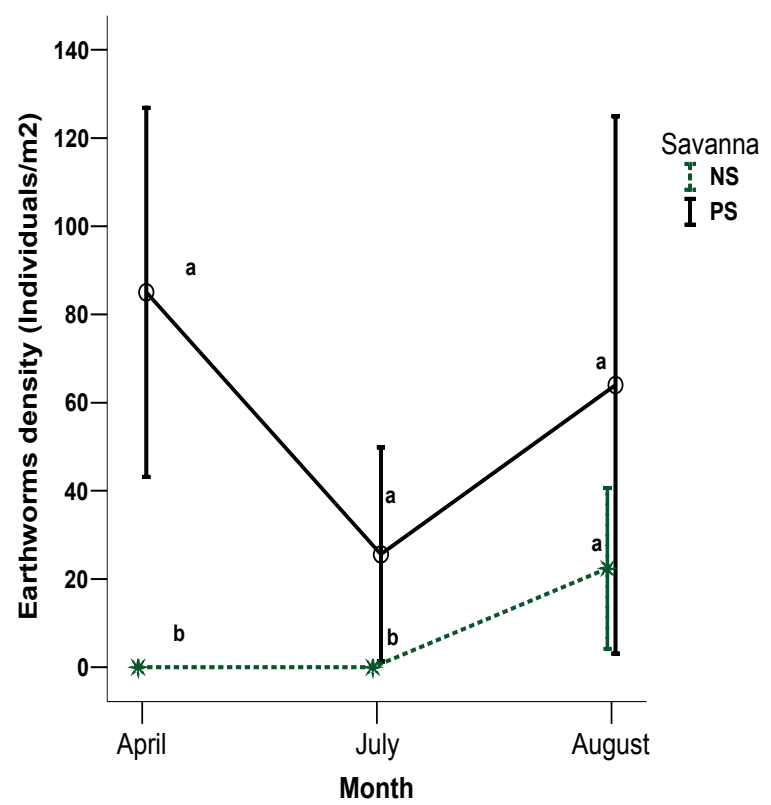

Figure3b. Mean density of earthworms (ind $/ \mathrm{m} 2$ ) and standard deviation in Protected Savanna (PS, continuous line) and Natural Savanna (NS, dashed line). Different letters indicate significant difference $(p<0.05)$. 


\subsection{Distribution by classes of stages of development}

Earthworms collected were separated into two developmental stages: juveniles and adults, cocoons were not found. Juveniles were dominant in both systems. In the PS, only in the month of maximum rainfall (August, Figure 2) were worms in adult stage found, representing $10 \%$ of the total number of collected individuals.

\section{Discussion}

4.1. Changes in soil physical, chemical and biochemical characteristics in the protected and non protected savannas

When fire is suppressed, vegetation develops from open savannas to densely wooded ecosystems, at least, in the most humid savannas as have been presented by research done in Africa (Vuattoux 1976) and America (San José and Fariñas, 1983). San José and Fariñas (1983) showed that after the establishment of the excluded area in 1960 the woody component of the savanna increased substantially in the EBLL. However Silva et al. (2001) have showed an increase of the woody component in both protected and nonprotected sites in the area. Moreover 25\% tree cover was reached in one of the unprotected savannas surrounding EBLL. Consequently, the savanna community changed in physiognomy from an open savanna and open parkland savanna to a more dense parkland savanna. Those tree encroachments are concomitant with the global $\mathrm{CO}_{2}$ increase of the last decades, which is more likely to be the most important factor in the general increase of tree encroachment in the whole area.
Long-term protection introduces significant changes not only in the physiognomy of the savanna but also in the EBLL soil's physical and chemical properties compared with the adjacent NS soil. The higher abundance of litter component in the soil surface of the PS may create the necessary conditions for a greater retention of moisture in the soil, which, in turn, affects earthworm's density, similar results have been presented by Araujo and López-Hernández (1999) and López-Hernández et al. (2004) for agroforestal systems located in sandy soils of Venezuelan Amazon.

Thus, in EBLL, protection has influenced some environmental parameters; particularly, soilmoisture contents have increased (Tables 1 and 4). The bulk density of the PS at the $0-10 \mathrm{~cm}$ depth was also lower than that of the NS; without doubt this result is a consequence of the higher compaction and lower organic content that occurs in the NS due to tillage management and cattle raising activities. López-Hernández et al. (2008) in comparative studies of soil physical parameters in the same protected and man-managed savannas have presented similar results. It seems possible that the management implemented in the NS in recent years (extensive cattle raising and conventional tillage) has been responsible for the presence of a sandy-loam textural class found in the first layer of soil $(0-10 \mathrm{~cm})$ that changed to loamy-sand at deeper depths. This may influence, directly or indirectly, the lower presence of earthworms at that depth because of the abrasive sand effect and/or alteration in the drainage of the soil.

Biological and biochemical properties are closely associated with many functions carried out in the soil, therefore these parameters are excellent 
indicators of soil quality (Defrieri et al. 2011; Stevanato et al. 2014).

The presence of an abundant litter layer above the soil have resulted in higher organic-C (Table 2) and soil parameters associated with fertility level (e.g. increase in total $\mathrm{N}$ and in a lesser extent $\mathrm{P}$ content). Moreover, microbial C-biomass and dehydrogenase activity have increased under protection in PS respect NS (Table 3) whereas urease and phosphatase activities were not afected by protection A similar result for phosphatase activities was found by López-Hernández et al. (2008) in another site at EBLL. Preliminary results presented by López-Hernández et al. (2008) showed that protection has also improved soil fertility, because of a reduction of compaction, an increase in the water holding capacity, organic matter, $\mathrm{pH}$, exchangeable bases, organic phosphorus and total phosphorus and nitrogen. Microbial C-biomass for the EBLL savannas were higher than the values presented by Gómez et al. (2008) and López-Hernández et al. (2009) in Trachypogon savannas of Eastern Llanos and Venezuelan Amazonia, respectively. On the contrary, the dehydrogenase values although greater in PS respect NS were lower than the information reported by López-Gutiérrez et al. (2004) and Gómez and Paolini (2011) in savannas of Eastern Llanos, Venezuela. The combination of both factors: higher fertility and less stress in microclimatic conditions create an environment more adequate for soil fauna; therefore, it has allowed the establishment and the dominance of earthworms, as well other components of the pedofauna populations. Pedofauna components, particularly earthworms, affect the soil physical properties of the soil through the construction of channels and galleries which in turn ameliorate soil structure and the soil water retention.

\subsection{Earthworm biomass abundance and density}

The improvement of the physical, chemical and biochemical conditions under protection (PS) induces better microclimatic and nutritional conditions for the proliferation of earthworms, which was reflected in a higher density and biomass of earthworms compared with NS during the month of April (end of the dry season) and July (wet season), in August although the mean values for density and biomass of earthworms were higher in PS respect NS, the values were very variable and the means did not reach significance perhaps affected by the excess of soil water in this month particularly in PS (Table 4). Araujo and López-Hernández (1999) have also recorded a drastic increase in earthworm density and biomass after the long-term organic amendment of the sandy savannas of Puerto Ayacucho, Venezuelan Amazonia. Also, similar results were reported in the Eastern Llanos of Carimagua, Colombia by Jiménez et al. (1998), where they found a yearly average of both earthworm density and biomass, of 57.8 individuals (ind) $\mathrm{m}^{-2}$ and 5.00 $\mathrm{g} \mathrm{m}^{-2}$, respectively. Those values significantly increased when the natural savanna was replaced by pasture species corresponding to a 17-year-grazed association between an exotic African grass, Brachiaria decumbens 
cv. Basilisk, and a tropical forage legume species, Pueraria phaseoloides (Jiménez et al., 1998). This association produces a high belowground production resulting in an increased availability of superficial litter residues and concomitant soil organic matter. The number and biomass of earthworms found in the non-protected (NS) Trachypogon savanna were low compared with other tropical sites. However, in the case of the PS, the biomass and density of earthworms exceeded the values reported by Jiménez et al. (1998) and Araujo and López-Hernández (1999) in neotropical savannas, although Jiménez et al. (1998) sampled until $60 \mathrm{~cm}$ depth.

\subsection{Classes of development stages}

During the dry season the earthworm population in the PS was dominated by juveniles, which could be a result of their better adaptability to those stress conditions or perhaps due to the seasonal rhythms of the population. At the peak of the rainy season a more pyramidal structural class was observed with a low percentage of adults in the population. Similar results to those presented in this study were found in Eastern Colombian and Southern Venezuelan savannas by Jiménez et al. (1998) and Araujo and LópezHernández (1999), respectively. The structure by classes of stages of development can vary for different taxa. The highest proportion in one of the classes depends on certain phases of the life cycle, the nature of the individual and its response to the environment at specific time of the year. In our periods of sampling the absence of cocoons in both systems studied was found.

In addition, it is notable that in environments where there is a well-defined dry season, as in this study, the deposition of cocoons could be limited to certain months, consequently due to our limited sampling we could not record cocoons presence. Thus, a special case of deposition of cocoons was presented by Jiménez et al. (1998) for the species Martiodrilus sp, where adults deposited their cocoons a month after that juvenile individuals begin their process of aestivation.

The correlations among earthworm biomass and density and soil physical parameters (Table 5) suggest that earthworms in PS can be limited by the amount of humidity present in the soil in different ways along the two seasons (dry and wet). During the dry season the availability of water positively affect the density of earthworms in PS. On the contrary, excess of humidity (waterlogging conditions) during the peak of the wet season (August, Figure 2 and Table 4) can negatively influence the biomass and density of earthworms (Table 5). Soil moisture content is not only important in terms of the water availability for the fauna, but also affects earthworm movement, soil resistance, thermic properties and gas transfer (Araujo and López-Hernández, 1999). Soil moisture, particularly in the wet season, regulates the increase in earthworm abundance and the rhythm of vital activities. The increase in abundance is not only a result of the higher soil moisture during the rainy season, but also a result of a rapid decomposition of litter during this season. 
Table 4. Soil water content (\%) in Protected (PS) and in man affected Natural Savanna (NS). Small letters indicate significant difference between depth and capital letters indicate significant difference between systems $(p<0.05)$.

\begin{tabular}{|l|l|l|l|l|l|l|}
\hline $\begin{array}{l}\text { Depth } \\
(\mathrm{cm})\end{array}$ & $0-10$ PS & $10-20$ PS & $20-30$ PS & 0-10 NS & $10-20$ NS & $20-30$ NS \\
\hline April & $2.3( \pm 1.8)$ & $4.4( \pm 1.9)$ & $5.3( \pm 1.2)$ & $1.8(( \pm 1.7)$ & $4.6( \pm 1.1)$ & $5.8( \pm 0.7)$ \\
& a, D & b, D & b, D & a, D & b, D & b, D \\
\hline July & $14.4( \pm 1.8)$ & $11.4( \pm 0.9)$ & $10.0( \pm 2.7)$ & $10.3(( \pm 1.1)$ & $9.0( \pm 1.8)$ & $11.1( \pm 1.4)$ \\
& a, D & a, D & b, D & a, F & a, D & a, D \\
\hline August & $17.6( \pm 2.3)$ & $15.8( \pm 1.1)$ & $15.3( \pm 1.2)$ & $13.1(( \pm 1.9)$ & $12.2( \pm 2.1)$ & $12.0( \pm 1.0)$ \\
& a, D & a, D & a, D & a, F & a, F & a, F \\
\hline
\end{tabular}

Table 5. Pearson's correlation coefficients between density and biomass of earthworms and soil variables in the PS in the dry season (above the diagonal) and the wet season (below the diagonal). * and ** significant at $P<0.05$ and 0.01 , respectively

\begin{tabular}{|c|c|c|c|c|}
\hline & Density & Biomass & Moisture & Temperature \\
\hline Density & 1 & $\mathbf{0 . 8 3 1 * *}$ & $\mathbf{0 . 5 3 3 *}$ & 0.364 \\
\hline Biomass & $\mathbf{0 . 7 0 1 * *}$ & 1 & 0.339 & 0.308 \\
\hline Moisture & $\mathbf{- 0 . 6 4 8 * *}$ & $\mathbf{- 0 . 6 7 7 * *}$ & 1 & -0.134 \\
\hline Temperature & $\mathbf{- 0 . 7 1 1 * *}$ & -0.488 & 0.403 & 1 \\
\hline
\end{tabular}




\section{Conclusions}

The protection of the savanna in the EBLL promotes an improvement in the physical, chemical and biochemical properties of the Oxisols studied. This may allow for an increase in the density and biomass of earthworms in the PS compared with the adjacent NS (less than 1 $\mathrm{km}$ apart) that is subjected to recurrent burning and grazing (Figure 1).

Therefore, we can emphasize the potential use of the density and biomass of earthworms as bioindicators of soil fertility and as active actors in the regeneration of the soil used as have previously reported. The majority of the individuals sampled were in juvenile stage; the adult specimens for taxonomic identification corresponded to the Glossoscolecidae family.

\section{Acknowledgements}

This study is part of the research project concerning: pedofauna activities in a long-term protected savanna, Guarico, State. Financial support was provided by Consejo de Desarrollo Científico y Humanístico-UCV (Proyecto PI 0300-6415-2006). We are grateful to the personal of the Estación Biológica los Llanos who allowed us to use their installations and provide us with information pertinent to the studied subject, also the División de Metereología de la Estación INIA, Calabozo gave us the precipitation records of the year of sampling. We would like to acknowledge Megan Mc Groddy of Environmental Science Department University of Virginia, Charlottesville, USA and Graham Martin of University of Cardiff, U.K. for their comments and revision of an early version of the manuscript. The authors would also like to thank an anonymous referee for constructive comments on the manuscript.

\section{References}

Anderson, J.M., Ingram, J.S. 1993. Tropical soil biology and fertility: a handbook of methods. Tropical Soil Biology and Fertility. ( $\left.2^{\text {nd }} e d\right)$. Wallingford, UK. pp. 16-18.

Araujo Y.M., López-Hernández, D. 1999. Earthworm populations in a savannaagroforestry system of Venezuelan Amazonia. Biol. Fertil. Soils. 29, 413-418.

Baker, G. 2007. Differences in nitrogen release from surface and incorporated plant residues by two endogeic species of earthworms (Lumbricidae) in a red brown earth soil in southern Australia. Eur. J. Soil. Biol. 43, S165-S170.

Blanchart, E., Albrecht, A., Alegre, J., Duboisset, A., Gilot, C., Pashanasi, B. Lavelle, P., Brussaard. L. 1999. Effects of earthworms on soil structure and physical properties, in: Lavelle, P., Brussaard, L., P. Hendrix,P., (Eds). Earthworm management in tropical agroecosystems. CAB. International. U.K., pp. 149- 172.

Brookes, P.C., Landman, A., Pruden, G., Jenkinson, P.D. 1985. Chloroform fumigation and the release of soil nitrogen: a rapid direct extraction method to measure microbial biomass nitrogen in soil. Soil Biol. Biochem. 17, 837-842.

Casida, L.E., Klein, D.A., Santoro, T. 1964. Soil dehydrogenase activity. Soil Sci. 98, 371-376.

Chaoui, H., Zibilske, L., Ohno, T. 2003. Effects of earthworm casts and compost on soil microbial activity and plant nutrient availability. Soil Biol. Biochem. 35, 295-302. 
Chapuis-Lardy, L., Le Bayon R.C., Brossard M., Lopez-Hernandez D., Blanchart E. 2011. Role of soil macrofauna in P cycling. in: "Phosphorus in Action -- Biological Processes in Soil Phosphorus Cycling", Bünemann E.K., Oberson A. and Frossard E. (Eds). Springer Soil Biology Series 26, Springer, NY, USA, pp. 199-213. DOI 10.1007/978-3-642-15271-9_8

Decaëns, T., Jiménez, J.J., Barros, E., Chauvel, A., Blanchart, E., Fragoso, C., Lavelle, P. 2004. Soil macrofaunal communities in permanent pastures derived from tropical forest or savanna. Agric. Ecosyst. Environ. 103, 301-312.

Defrieri, R.L., Sarti, G., Tortarolo, M.F., Escobar-Ortega, J., García de Salamone, I.,D'Auria, F., Effron. D. 2011. Biochemical and microbiological properties of Argentinean Patagonia soil with implanted forest species Journal of Soil Science and Plant Nutrition. 11, 111-124

Gomez, Y., Paolini J. 2011. Variación en la actividad microbiana por cambio de uso en suelos en sabanas, Llanos Orientales, Venezuela. Rev. Biol.Trop. 59 (1), 1-15.

Gomez, Y, Paolini, J., Hernández, R.M. 2008. Sustitución de la sabana nativa con plantaciones de Pinus caribaea (Pinaceae) en Venezuela: efecto sobre parámetros indicadores de cambiosen el carbono del suelo. Rev. Biol. Trop. 56 (4), 2041-2053.

Hernández, L., Ojeda, A., López-Hernández, D. 2012. Características bioecológicas en poblaciones de lombrices (Oligochaeta, Glossoscolecidae) de una sabana natural y una sabana protegida en los llanos centrales de Venezuela. Rev. Biol. Trop. 60 (3), 1217 1229 .
Jiménez, J.J., Moreno, A., Decaëns, T., Lavelle, P., Fisher, M., Thomas, R. 1998. Earthworm communities in nature savannas and manmade pastures of the Eastern plains of Colombia. Biol. Fertil. Soils. 28, 101-110.

Jiménez, J.J., Cepeda, A., Decaëns, T., Oberson, A., Friesen. D. 2003. Phosphorus availability in casts of an anecic savanna earthworm in a Colombia Oxisol. Soil. Biol. Biochem. 35, 715-727.

Lavelle, P., Spain, A.V. 2001. Soil Ecology. Kluwer Academic Publishers, London, U.K., pp 485.

Lavelle, P., Dangerfield, M., Fragoso, C., Eschenbrenner, V., López-Hernández, D., Pashanasi, B., Brussaard, L. 1994. The relationship between soil macrofauna and tropical soil fertility, in: Woomer. O.L., Swift. M.J. (Eds.), The Biology Management of Tropical Soil Fertility, TSBF: A WileySayce Publication, pp. 137-169.

López-Gutiérrez J.C., Toro, M., LópezHernández. 2004. Seasonality of organic phosphorus mineralisation in the rhizosphere of the native savanna grass, Trachypogonplumosus. Soil Biology and Biochemistry. 36, 1675-1684.

López-Hernández, D. 2012. Earthworm populations in savannas of the Orinoco Basin. A review of studies in long-term agricultural-managed and protected ecosystems. Agriculture. 2, 87-108.

López-Hernández, D., Hernández-Valencia, I., Guerere, I. 2008. Cambios en parámetros físicos, químicos y biológicos en el suelo de una sabana protegida de quema y pastoreo durante veinticinco años. Bioagro. 20, 151158. 
López-Hernández, D., Lavelle, P., Fardeau, J.C., Niño, M. 1993. Phosphorus transformations in two P-sorption contrasting tropical soils during transit through Pontoscolex corethrurus (Glossoscolecidae: Oligochaeta). Soil Biol. Biochem. 25, 789-792.

López-Hernández, D., Hernández, C.L., Netuzhilin, I., López-Contreras. A.Y. 2009. Agricultural Systems Located in the Forest-Savanna Ecotone of Venezuelan Amazonian. Are Organic Agroforestry Farms Sustainable?. Sustainability. 1, 215-233.

López-Hernández, D., Araujo, Y., LópezContreras, A.Y., Hernández-Valencia, I., Hernández, C. 2004. Changes in soil properties and earthworm populations induced by long-term organic fertilization of a sandy soil in the Venezuelan Amazonia. Soil. Sci. 169, 188-194.

Paoletti, M. 1999. The role of earthworms for assessment of sustainability and as bioindicators. Agric. Ecosys. Environ. 74, 137-155.

San José, J.J., Fariñas, M. 1983. Changes in tree density and species composition in a protected Trachypogon savanna, Venezuela. Ecol. 64, 447-453.

San José, J.J., Fariñas, M. 1991. Temporal changes in the structure of a Trachypogon savanna protected for 25 years. Acta Oecol. $12,237-247$.
Silva, J.F., Zambrano A., Fariñas, M.R. 2001. Increase in the woody component of seasonal savannas under different fire regimes in Calabozo, Venezuela. J. Biogeogr. 28, 977983.

Stevanato, P., Bertaggia, M; Stellin, F., Rizzi, V., Piffanelli, P., Angelini, E., Bertazzon, N., Fornasier, F., Squartini, A., Saccomani, M., Concheri, G. 2014. Soil biological and biochemical traits linked to nutritional status in grapevine. Journal of Soil Science and Plant Nutrition. 14, 421-432.

Tabatabai, M. A., Bremner, J. M. 1969. Use de p-nitrophenyl phosphate for assay of soil phosphatase activity. Soil. Biol. Biochem. 1, 301-307.

Tabatabai, M.A., Bremner, J.M. 1972. Assay of urease activity in soils. Soil. Biol. Biochem. 4, 479-487

Vance, E.D., Brookes, P.C., Jenkinson, D.S. 1987. An extraction method for measuring soil microbial biomass C. Soil. Biol. Biochem. 4, 703-707.

Vuattoux, R. 1976. Contribution à l'étude de l'évolution des strates arborées et arbustives dans la savane de Lamto (Côte d'Ivoire). Deuxième note. Ann. Univ. Abidjan, série C, tome XII, 35-63. 